Meta

Journal des traducteurs

Translators' Journal

\title{
Functions of Translation in Post-Colonial India
}

\section{Shantha Ramakrishna}

Volume 42, numéro 2, juin 1997

Lexicologie et terminologie II (1) et Traduction et post-colonialisme en Inde

Translation and Postcolonialism: India (2)

URI : https://id.erudit.org/iderudit/003912ar

DOI : https://doi.org/10.7202/003912ar

Aller au sommaire du numéro

Éditeur(s)

Les Presses de l'Université de Montréal

ISSN

0026-0452 (imprimé)

1492-1421 (numérique)

Découvrir la revue

Citer cet article

Ramakrishna, S. (1997). Functions of Translation in Post-Colonial India. Meta 42(2), 444-449. https://doi.org/10.7202/003912ar

\section{Résumé de l'article}

Pour comprendre la fonction de la traduction dans l'Inde post-coloniale, nous devons tenir compte de l'influence de cette activité sur l'image de l'Inde des orientalistes, ainsi que sur le rationalisme anti-colonial qui s'est opposé à la domination britannique dans un mouvement d'affirmation historique et identitaire. Aujourd'hui, en Inde, la traduction est reconnue et sert de lien entre les différents groupes linguistiques, jouant un rôle actif dans l'identité nationale. En Inde, peut-être plus que dans d'autres pays anciennement colonisés, il est possible d'écrire dans sa propre langue. À l'ère post-coloniale, il s'agit là d'un puissant outil d'affirmation culturelle. 


\title{
FUNCTIONS OF TRANSLATION IN POST-COLONIAL INDIA
}

\author{
SHANTHA RAMAKRISHNA \\ Centre for French Studies, Jawaharlal Nehru University, New Delhi, India
}

\begin{abstract}
Résumé
Pour comprendre la fonction de la traduction dans l'Inde post-coloniale, nous devons tenir compte de l'influence de cette activité sur l'image de l'Inde des orientalistes, ainsi que sur le rationalisme anti-colonial qui s'est opposé à la domination britannique dans un mouvement d'affirmation historique et identitaire. Aujourd' hui, en Inde, la traduction est reconnue et sert de lien entre les différents groupes linguistiques, jouant un rôle actif dans l' identité nationale. En Inde, peut-être plus que dans d'autres pays anciennement colonisés, il est possible d'écrire dans sa propre langue. À l'ère post-coloniale, il s'agit là d' un puissant outil d'affirmation culturelle.
\end{abstract}

\begin{abstract}
To comprehend the function of translation in post-colonial India, we must take into consideration its function in shaping the Orientalists' image of India, as well as in the anticolonial rationalism which responded to British rule by asserting its claims to history and identity. In post-colonial India, officially recognized and supported translation activities mediate between different linguistic group within the nation and seek to promote national unity and identity. More than anywhere else in the post-colonial world perhaps the possibility of writing in one's own language exists in India. Such writing becomes a powerful element in postcolonial self assertion.
\end{abstract}

The term "Post-Colonial" would seem to refer solely to the period after the departure of an imperial power from its former colonies. It has indeed been used to distinguish between the periods before and after independence. However, we shall use this term to cover the period from the moment of colonization to the present day, as suggested by Ashcroft et al. (1989). To comprehend the functions of translation in post-colonial India, we must take into consideration its function in shaping the Orientalist's image of India as well as in the anti-colonial nationalism which responded to British rule by asserting its claim to history and identity.

Orientalism, from the very beginning a purely European enterprise, looked upon Indians as inert objects of knowledge (Prakash 1992: 355). After the conquest of Bengal in 1757, the East India Company required its officers to have knowledge of the conquered people. Administrators of the Company learned Persian and Sanskrit and soon began to collect manuscripts, and to translate and publish texts. Thanks to the initiatives of William Carey, N.B. Halhead, William Jones, H.T. Colebrooke, Francis Gladwin and others, translations and commentaries flourished. With the foundation of the Asiatic Society and publications in research journals, the Orientalists' knowledge spread to European universities: "[...] the discovery of affinities between Sanskrit and European langauges provided the premise for formulating the belief in an 'Aryan race' from which the Europeans and Brahmins were seen to originate." (Prakash 1992: 356). Many of the translations in this period were born out of a genuine desire to know more about the Orient. Though it has now become cliched for post-colonials to highlight only the negative impact of colonial translation on the Indian psyche and the Orientalist's attempt to project the colonized as 
an Other without identity of its own, it must be acknowledged that the Orientalists' untiring labour as translators had a key role in promoting comparative studies in Europe and in reviving interest in the vernaculars. Under Moghul patronage Persian had overshadowed Sanskrit and other languages. But the initiative of the early Orientalists in regard to translations not only from Sanskrit but also into Sanskrit and other vernaculars (especially through Bible translations in the latter case) was instrumental in reviving interest in these vernaculars, including Bengali. For instance, the pioneering role of William Carey in this respect was recognized "by no less a literary figure than Tagore."1

But the picture soon changed. Translation quickly came to serve as a tool in the domestication of the Orient. Over the course of time Eurocentric ideas were applied in all areas, even in science. Translations and commentaries were used to represent Indians as incapable of change and to justify the British in their self-proclaimed role as modernizers. The Orientalists' projects of translation helped to introduce British education. English became the medium of communication for the Indian intelligentsia throughout the country, and served as a force for administrative convenience. As Gauri Viswanathan (1987: 17) points out, "British colonial administrators, provoked by missionaries on the one hand and fears of native insubordination on the other, discovered an ally in English literature to support them in maintaining control of the natives under the guise of a liberal education."

The dominant imperial language and culture were privileged over the existing traditions of the people and contributed to destroy the natives' instruments of expression. Translation helped to promote not only the commercial and legal interests of the British, but also their educational and linguistic needs as well, and thereby served as a major instrument in colonial domination.

The first significant challenge to orientalized India came with the rise of nationalism. The myopic Eurocentric view that anything worthy of emulation originated in Greece was challenged and the Orientalists' authority to speak of India was contested. A commitment was made to spread education in the vernacular. Many Indian intellectuals of the nineteenth century believed that science was culture and that it should be taught in the vernaculars. They were convinced that these were the only media through which knowledge could be disseminated to the masses. The translation of science was to serve to articulate a countercolonial political stance (Habib and Raina 1989:606) and became a way to oppose the cultural and intellectual erosion which had taken place under colonial rule.

In 1843 a vernacular translation society was set up at Delhi College; its task was to translate books from English into the vernaculars. Sir Syed Ahmad Khan expressed the need for translation on a massive scale as follows:

Those who are bent on improving and bettering India must remember that the only way of encompassing this is by having the whole of Arts and Sciences translated into their own languages. I should like to have this written in gigantic letters on the Himalayas for the remembrance of future generations. (Habib and Raina 1989:605)

Maulana Imdad Ali, who founded the Bihar Science Society in 1868 for the purpose of spreading scientific knowledge through the use of Indian languages, wrote: "England, France, and Germany would never have attained that exalted degree of civilization which they now enjoy if the works of Sciences, originally imported from Rome and Greece in Latin and Greek, were not disseminated among the people by means of their own vernaculars." (Habib and Raina 1989: 605) The Science Society translated books on a wide range of scientific subjects, and scholars such as Master Ramachandra translated into the vernaculars in order to build up national character. Thus the translation of science served as a force for national unity and to develop national consciousness, and translation in general asserted itself as an act of resistance to the imperialist process. 
During the independence struggle the fervour for substituting an Indian language for imperial English was built on nationalist aspirations. Mahatma Gandhi clearly saw that English could in no circumstances be the national language of India and that it would have to be replaced by Hindustani if the movement was to evoke the support of the masses: "Our love of the English language in preference to our own mother tongue has caused a deep chasm between the educated and the politically-minded classes and the masses." (Gandhi 1965: 5) He felt that the greatest service one could do to the nation under the circumstances was to turn oneself to one's language, adopt Hindi as the national language, perform national-level work in Hindi and regional-level work in regional languages. Thus the hierarchical structure of power perpetuated through the medium of the English language and English conceptions of truth and order vehiculed through the medium were being rejected in favour of Indian languages with the emergence of a post-colonial voice.

To fully comprehend and appreciate the functions of translation in post-independence India we have to keep in mind the following elements: multilingualism is a matter of reality for Indians; language issues in India as in other plurilingual societies have psychological as well as emotional reality. "Nowhere in Hindustan is the language of the village the same as the language of the court and the school," Sir George Abraham Grierson observed almost a century ago, on September 27,1886 . With the movement of people between regions and states multilingualism is constantly on the increase.

Recognizing the fact that it is the diversity of our languages which has kept the country's composite cultural make-up alive the Constitution of India has ensured the plurilingual fabric of Indian society by incorporating the provisions of the Official Languages Act at the union and state levels and in the judiciary. Further, under the provisions of the constitution, any citizen of India is entitled to submit a representation for the redressal of a grievance to any officer or authority of the Union or of a State in any of the languages used in the Union or the State, as the case may be. The inclusion of a language in the Eighth Schedule of the Constitution bestows recognition and status upon that language, whereas lack of recognition could eventually lead to its absorption by the dominant language of the region. Thus there is an underlying play of power and dominance between languages which could result in an absence of commitment to the other language or culture, especially when the other happens to be a minority culture and language.

The Constitution has made the promotion of Hindi mandatory. It has stipulated that Hindi should be enriched and modernized by the assimilation of forms, styles and expressions used or current in Hindustani and different regional languages. This new vocabulary is to be drawn from Sanskrit and secondarily from other Indian languages. Nearly $57 \%$ of the Indian population use Hindi for intergroup communication. A sizeable percentage of the population in the southern states is bilingual $(17,4 \%$ of the speakers of Malayalam, $9,69 \%$ of Tamil, $6,81 \%$ of Telugu, and $6 \%$ of Kannada), with Hindi as one of the languages, and tribals, who according to Abbi constitute the largest group of bilinguals in the country, use Hindi in intergroup communication with non-tribals. The phenomenal growth of the Hindi language is not due merely to constitutional provisions for promoting Hindi, but also due to curiosity for other cultures.

The Official Languages Act of 1963 provides for translation into Hindi and into the regional languages recognized as official languages. English, Hindi and the regional languages are considered to have symmetrical functions and equality of status, rights and privileges in all institutions of the government and the parliament. All forms pertaining to contracts, agreements, licenses, permits, notices, tenders covered by sub-section 3 (3) iii of the Official Languages Act and all codes and manuals of different Ministries are to be translated from English into Hindi or into the regional languages, according to the needs of the situation. 
The Commission for Scientific and Technical Terminology set up in 1961 has prepared dictionaries and glossaries, in English and Hindi, relating to science, engineering, agriculture, social sciences, computer sciences, mineralogy, zoology, electronics, etc. Provision has been made for reviewing these terminologies from time to time and for including appropriate new words and expressions which become required due to scientific innovation. The Commission has emphasized the need to publish works on science and technology in Hindi, to translate into Hindi and other Indian languages the scientific and technological knowledge available in other languages and to prepare glossaries, dictionaries, university-level manuals and books, and supplementary literature in various disciplines of science and technology. The Commission of Parliament has recommended that arrangements should be made for direct translation of manuals, etc., from foreign languages into Hindi at the School of Foreign Languages run by the Ministry of Defence. Thus officiallyrecognized and supported translation activities mediate between different linguistic groups within the nation and seek to promote national unity and identity.

Though a great deal of emphasis has been laid on developing glossaries and on translating science books into the Indian languages, not much in these areas has in fact been achieved. Science education has greatly expanded in developing countries in the post-colonial period. Contrary to what has been provided for by the Commission for Scientific and Technical Terminology and by the provisions of the Official Languages $A c t$, the increase in the teaching of science has actually strengthened the traditional structures of language dominance, with emphasis being placed on the language with the widest communication, that is, on English. This has serious implications not only for policy related to and the dissemination of science but also for the maintenance and enrichment of multilingualism. As has rightly been pointed out by Dr. Hans Raj Dua, major Indian languages must play a constitutive role in the education system in order to bring about an integrated development of language, culture, and science. In our opinion, translation has a constructive role to play in such a development. In ancient days the language for science was fully developed. Works such as Brahmasputa Siddhanta, Caraka, Susruta Samhita were drafted directly in Sanskrit. Such is not the case today. Indian languages have not yet developed fully enough to be able to cope with the ever-expanding frontiers of science and technology.

Yet another point needs to be taken note of. What will be the fate of minority or lesser-used languages against the backdrop of the New Economic Policy in a multilingual setting such as that of India? What will be the impact of the policy of economic liberaljzation on language use with regard to both majority and minority languages? Willingness to learn the other language becomes less a matter of cultural curiosity than a matter of economic necessity. Translation and the preparation of terminology is bound to gather speed in the languages of the region which attract foreign investments.

There are many forms of translation activity which are not specifically provided for under the Official Languages policy and which nevertheless contribute to maintaining India as a multilingual and multicultural nation. Literary translation is one such form, carried out as a result of individual efforts and encouraged as well by organisations such as the Sahitya Akademi (the national Academy of Letters), Katha, the National Book Trust, and several publishing houses.

Before independence there were people who learned other languages and this happened as a normal course of events. People believed that "to learn a new language is to gain the membership of a new community, a new freedom." (Kelkar 1992 : 34) Since independence, however, interest in learning each other's language has faded. This has culminated in the practice of translating through English or Hindi. 
"This imperialist-orientalist disorientation is still with us today. [...] It is not only Persian language and literature to which we now need access through the mediation of the English language; we have proceeded to seek and prefer this mediation in order to have access to the literature of other languages nearer home: Hindi, Bengali, Marathi, Urdu - languages which we call 'our own'." (Trivedi 1993: 54) There is a problem in this statement. If we analyze some of the available data we find that what is stated is only partially true in present-day India, and that there are exceptions. To cite an example: at the National Book Trust, direct translation is carried out for at least four or five Indian languages. People are becoming more and more conscious that the translation of a literary work from one Indian language into as many Indian languages as possible will achieve the target of the largest possible Indian audience. Literature will come close to the heart, encompassing the socio-cultural ethos of the audience group and thus promote unity while preserving diversity.

Many authors take the position that translation into English offers the widest area of discovery and that English is the only link language in India which can provide a common, unifying ground. This is true only to the extent that English is the language of use in education and in administration. For the same reasons it is considered to be an elite language. The question remains whether the elite should be defined in relation to a knowledge of English or using economic and socio-political criteria. In today's India, it is more the latter. Further, more than anywhere else in the post-colonial world perhaps, the possibility of writing in the vernacular languages exists in India. Such writing has become a powerful element in post-colonial self-assertion, and writing in English represents only a small and marginal aspect of the practice of contemporary Indian writing. This has resulted in the need for extensive translations into English from Indian languages to be produced.

It is often asserted that through translation some languages receive more than they transmit. Thus the number of books translated into Hindi seems larger than those translated into any other Indian language. Languages such as Bengali and Tamil are perceived as being indifferent to other Indian languages and as suffering from a sense of superiority. On the one hand this might be a legacy of history, as these languages were enriched by the works of indologists and hence never felt the need to receive other Indian languages or to gain membership into other communities. On the other hand, it might be due to the fact that 'Hindiphones' outnumber other-language speakers. However, we need to carry out a proper statistical survey before drawing hasty conclusions that one language is insular as compared to another, which is more receptive and other-culture friendly. We should be wary of perpetuating colonial paradigms.

What precedes leads us to emphasize the following factors:

- Officially recognized and supported translation activities have as their main aim the ensurance of better administration, of equal access to the judicial system, and of national unity, by opening up communication between the masses and the state. Although the government recognizes the importance of preserving and enhancing the use of languages other than the official languages, the concern for strengthening the use of Hindi as the national language has led to certain imbalances in the development of other Indian languages. Under such circumstances minority languages tend to be further marginalized.

- The spread of scientific education after independence has strengthened English, the language of wider communication. Indian languages cannot be considered as fully developed until they are equipped to cope with new expressions arising out of scientific innovation.

- The New Economic Policy will strengthen the structures of language dominance through the development given to the languages used by investors and to the regional languages of the states where investment is taking place.

- Literary translation usually takes place between well-developed languages. 
These factors have serious implications for the maintenance and enrichment of multilingualism and multiculturalism. As Kelkar (1992: 34) observes: "The major languages of Europe modernized themselves over a period of four centuries. Indian languages cannot afford to wait that long." Language development should become the concern not only of educators, authors, journalists and the mass media, but also of translators, for languages develop not only through use but also through translation. Translations are called for into Indian languages which have so far remained less receptive to other Indian languages and cultures; conscious efforts should be made to further develop minor languages by translating from and into these languages. Non-availability of material in translation prevents us from getting the total picture of a culture and hampers the scientific, technological and economic development of a society. For languages to be maintained they must be used in every field, and for languages to be used in all fields, technical and scientific information that is not already available to them must be translated.

The main functions of translation in post-colonial India would therefore be to make available cultural parallels between Indian languages on the one hand, and on the other to equip them to cope with communication on planes other than the purely literary. "The post-colonial world is one in which destructive cultural encounter is changing to an acceptance of difference on equal terms" (Ashcroft et al. 1989:36), and translation has a fruitful role to play in facilitating such acceptance.

Note

1. Pearce Carey cited by Chrysostom Arangaden and John Philipose in the International Journal of Translation, vol. IV, n $1-2,1992$, p. 11 .

\section{REFERENCES}

ARANGADEN, Chrysostom and John PHILIPOSE (1992): "Carey's Legacy of Bible Translation", International Journal of Translation, vol. IV, $\mathrm{n}^{\circ} 1-2$.

ABBI, Anvita (1995): "India's Multi-lingual Patterns", The Book Review, XIX, 8.

ASHCROFT, Bill, GRIFFITHS, Gareth and Helen TIFFIN (1989): The Empire Writes Back, London and New York, Routledge.

DUA, Hans Raj (1996): "Science Education, Language Dominance, and Multilingualism", presented at the national seminar on "Translation and Multilingualism in Post-Colonial Contexts: Indian and Canadian Experiences", School of Languages, Jawarhalal Nehru University, New Delhi.

GANDHI, M. K. (1965): Our Language Problem, Bombay, Bharatiya Vidya Bhavan.

HABIB, Irfan and Dhruv RAINA (1989): "The Introduction of Scientific Rationality into India: A Study of Master Ramachandra - Urdu Journalist, Mathematician and Educationalist", Annals of Science, 46, pp. 597-610.

KELKAR, Ashok R. (1992): "Language Planning in India: A Case Study in Marathi", The Administrator, Mussorie, XXXVII (October - December 1992), pp. 29-44.

PRAKASH, Gyan (1992): "Writing Post-orientalist History of the Third World: Indian Historiography is Good to Think", Colonialism and Culture, Nicholas B. Dirks (Ed.), The University of Michigan Press, pp. 353-388.

TRIVEDI, Harish (1993): Colonial Transactions, Calcutta, Papyrus.

VISWANATHAN, Gauri (1987): "The Beginnings of English Literary Study in British India", Oxford Literary Review, IX, $1 / 2$. 